\title{
Pemilihan Presiden Ideal Melalui Demokrasi Kerakyatan Berdasarkan Nilai - Nilai Keislaman
}

\author{
M. Junaidi \\ Fakultas Hukum Universitas Muhammadiyah Surakarta \\ mj122@ums.ac.id \\ Dania Nalisa Indah \\ Fakultas Hukum Universitas Muhammadiyah Surakarta \\ dania.nalisa95@gmail.com
}

DOI: $10.23917 /$ laj.v5i1.10781

Submission

Track:

Received:

10 Januari 2020

Final Revision:

14 Februari 2020

Available online:

28 April 2020

Corresponding

Author:

M. Junaidi

mj122@ums.ac.id

\begin{abstract}
ABSTRAK
Indonesia merupakan negara yang sistem penyelenggaraan negaranya berdasarkan asas kedaulatan rakyat dan prinsip negara hukum. Salah satu bentuk dari pelaksanaan asas kedaulatan rakyat adalah dengan memberikan kesempatan kepada rakyat untuk berpartisipasi dalam pemilihan presiden secara langsung karena Indonesia sebagai penganut sistem pemerintahan presidensiil, presidennya hanya memiliki masa jabatan yang berlangsung selama 5 (lima) tahun. Meskipun begitu, pemilihan secara langsung yang sudah dimulai semenjak tahun 2004 hingga yang terakhir 2019 ini dinilai sudah tidak sesuai dengan nilai - nilai Pancasila yang merupakan grundnorm dari segala konstitusi yang berlaku di Indonesia. Sehingga muncul sebuah tantangan untuk mencari suatu pemilihan presiden ideal di Indonesia yang sesuai dengan Pancasila serta bernilai keislaman agar dapat diterima dengan baik oleh masyarakat Indonesia yang mayoritas adalah pemeluk agama islam. Metode penulisan yang digunakan adalah studi kepustakaan. Hasilnya menunjukan bahwa tantangan ini dapat diatasi dengan mengusung kembali demokrasi kerakyatan berlandaskan sila ke-4 Pancasila yang berbunyi, "Kerakyatan yang dipimpin oleh hikmat kebijaksanaan dalam permusyawaratan/perwakilan" yang sebenarnya sudah pernah dilakukaan pada masa lampu yaitu dengan cara pencalonan dan bermusyawarah sebagaimana salah satu praktik pemilihan pemimpin yang berasaskan nilai - nilai keislaman. Sehingga nantinya selain Indonesia berhasil menjalankan konstitusinya dengan baik, peyelenggaran demokrasi Indonesia kembali pada makna demokrasi yang diinginkan
\end{abstract}


oleh para The Founding Fathers.

Kata Kunci: Demokrasi Kerakyatan, Pancasila, Pemilihan Umum (Pemilu)

\section{PENDAHULUAN}

Semenjak tahun 2004, dalam melaksanakan pemilihan umum (pemilu) Indonesia mulai melaksanakan pemilu secara langsung dimana setiap warga negara Indonesia (WNI) yang sudah dewasa secara konstitusi memiliki hak untuk memberikan satu suara kepada calon presiden yang dipilihnya baik yang sedang berada di Indonesia maupun yang sedang berdiam diluar negeri. Tidak seperti masa - masa sebelumnya yang hanya bisa memilih perwakilan (partai) untuk mewakilkan suaranya dalam pemilihan kepala negara dan kepala pemerintahan di tingkat yang lebih tinggi. Penyelenggara negara merasa bahwa pemilihan langsung merupakan salah satu cara mereka untuk melaksanakan asas kedaulatan rakyat dimana rakyat dapat berpartisipasi memberikan kontribusinya untuk menentukan kelangsungan negara Indonesia kedepannya sesuai dengan yang ditetapkan pada Undang - Undang Dasar Republik Indonesia 1945 (UUD RI 1945) Pasal 1 Ayat (2) yang berbunyi, "Kedaulatan berada ditangan rakyat dan dilaksanakan menurut Undang Undang Dasar".

Hasil survei yang dilakukan oleh Saiful Mujani Research \& Consulting (SMRC) menunjukkan ada 69\% responden yang menilai bahwa Pemilu yang berlangsung pada 2019 sudah berlangsung jujur dan adil (jurdil). Dari hasil survei tersebut dapat dilihat bahwa terjadi penurunan kepuasan masyarakat Indonesia akan adanya pemilihan langsung karena pada tahun 2014, SMRC mendapatkan hasil 70,7\% responden yang menganggap bahwa pemilu yang dilakukan sudah berlangsung secara jurdil (CNN Indonesia, 2019). Adapun tingkat kepuasan masyarakat atas kinerja presiden dan wakil presiden pada periode sebelumnya pun sudah berada pada nilai yang cukup menyenangkan. Pada akhir periodenya berdasarkan survei yang dilakukan oleh Litbang Kompas, 58.8\% masyarakat Indonesia sudah puas akan kinerja mereka (Movanita, 2019).

Tetapi, sistematika pemilu yang dilakukan secara langsung dan diterima dengan baik oleh masyarakat ini ternyata tidak sesuai dengan Pancasila yang merupakan grundnomn dari segala pelaksanaan konstitusi di Indonesia terutama pada Sila Ke-4. Pemilu langsung 
ini sudah sangat jelas bertentangan dengan sila tersebut karena mengesampingkan unsur permusyawaratan dan perwakilan. Hal itu juga sejalan dengan ajaran Siyasah (Hukum Tata Negara) yang ada dalam agama Islam, dimana dalam memilih seorang pemimpin atau biasa kita sebut khalifah salah satu yang digunakan adalah musyawarah karena pada dasarnya sebagai negara yang mayoritas warga negaranya adalah pemeluk agama Islam tentunya banyak dari peraturannya yang mengadaptasi hukum dalam agama Islam.

Padahal unsur itulah yang nilai yang terkandung dalam ajaran Pancasila yang mencerminkan gotong royong bukannya nilai individualistis yang berkembang dalam demokrasi saat ini. Maksud dari nilai individualistis ini terletak pada sikap egois partai politik yang berlomba - lomba mencari suara untuk menanamkan pengaruhnya di kursi pemerintahan. Sistem yang dihasilkan pada era reformasi ini malah menciptakan persaingan yang tidak sehat karena memunculkan cara - cara kapitalis yang transaksional dan menghasilkan pemimpin yang tidak bertanggung jawab kepada rakyat melainkan lebih condong untuk berkontribusi kepada partai. Sehingga perlu dicari kembali pemilihan ideal yang sejalan dengan Pancasila terutama pada Sila Ke-4 dimana dalam pemilihan ini juga tidak bertentangan dengan nilai - nilai keislaman karena salah satu dari tugas sebuah negara adalah untuk menjaga agama dengan cara menjalankan apa yang sudah diperintahkanNya dalam kitabNya.

\section{TEORI DAN METODELOGI}

Demokrasi kerakyatan biasa disebut demokrasi pancasila yaitu suatu paham demokrasi yang bersumber dari pandangan pelaksanaannya telah sesuai dengan cita-cita yang luhur, watak, dan kepribadian hidup atau falsafah hidup bangsa Indonesia yang digali berdasarkan kepribadian bangsa Indonesia. Pelaksanaan demokrasi berarti menjaga persatuan dan kesatuan bangsa dan negara, saling menghargai serta selalu bermusyawarah dalam menyelesaikan berbagai permasalahan. Pelaksanaan demokrasi dalam kehidupan masyarakat Indonesia telah banyak dituangkan dalam pilar-pilar demokrasi yang menunjang kelangsungan hidup demokrasinya.

Salah satu tokoh Indonesia yang terkenal dengan gagasan demokrasi kerakyatannya adalah Moh.Hatta. Beliau mengatakan bahwa demokrasi barat yang dimana seperti kita ketahui diterapkan dalam demokrasi era reformasi ini tidak sesuai dengan apa yang Indonesia cita - citakan. Maksud dari demokrasi barat disini adalah demokrasi yang 
berdasarkan individualisme, dimana kala itu sangat gencar dipraktikan pada masa Revolusi Prancis yang mengarah pada kemerdekaan, kebenaran serta kebebasan bagi setiap individu memicu timbulnya sikap egois karena ingin mempertahankan kedudukannya masing - masing dimata hukum dan negara. Demokrasi yang seperti ini hanya mempersoalkan rakyat dibidang politik, sedangkan di bidang ekonomi yang berkuasa hanya kaum pemodal. Demokrasi yang seperti inilah yang menciptakan kapitalisme di bidang ekonomi yang sedang terjadi di Indonesia.

Sifat demokratis rakyat Indonesia ini bersumber dari semangat kebersamaan atau koletivisme yang hidup dari hati nurani setiap anggota masyarakat asli. Menurut pandangan beliau, nilai kebersamaan ini melahirkan tiga ciri yaitu rapat atau musyawarah, mufakat dan tolong menolong (Sutrisno, 2013). Dua ciri pertama berhubungan dengan cara - cara yang dapat dilakukan dalam mengambil keputusan yang berhubungan dengan kepentingan bersama. Dua nilai inilah yang melandasi Sila Ke-4 Pancasila dan dapat diterapkan dalam sistem ketatanegaraan Indonesia.

Demokrasi kerakyatan yang digagas oleh Hatta memiliki beberapa lapisan. Dimana jika dijabarkan adalah sebagai berikut:

1. Lapisan pertama dimulai tingkat desa, dimana disini wakil rakyat dapat dipilih secara langsung oleh warga desa.

2. Lapisan kedua adalah Dewan Perwakilan Rakyat tingkat provinsi yang masih dipilih secara langsung oleh warga Indonesia yang ada di provinsi tersebut.

3. Lapisan ketiga adalah Dewan Perwakilan Rakyat tingkat nasional yang dipilih oleh DPR tingkat provinsi (Sutrisno, 2013).

Kemudian dalam tingkatan yang lebih tinggi, terutama untuk pemilihan presiden maka yang berhak memilih adalah wakil - wakil rakyat yang sudah duduk dalam pemerintahan tersebut. Pemilihan yang berlangsung berasaskan asas gotong-royong dan musyawarah mufakat karena pada zaman tersebut belum ada. Sayangnya beliau tidak menjelaskan lebih lanjut kriteria calon wakil rakyat pada lapisan pertama dan kedua yang bagaimanakah yang layak maju untuk daerah yang dijagokannya. Maka perlu penyempurnaan lagi, dimana penyempurnaan ini dapat ditambahkan dengan nilai - nilai keislaman.

Dalam Islam, salah satu cara untuk mengangkat kepala negara adalah dengan cara dipilih oleh kalangan ahlul-halli wal-'aqdi dengan cara melakukan sidang untuk 
mempelajari dan menyepakati siapa yang berhak untuk memangku jabatan kepemimpinan negara tersebut (Al-Mawardi, 2000). Dimana orang - orang yang memilih ini pun juga harus memenuhi beberapa kriteria diantaranya adalah:

1. Kredibilitas pribadinya atau keseimbangan (al-'adalah) memenuhi semua kriteria;

2. Mempunyai ilmu pengetahuan yang cukup sehingga mampu memutuskan siapakah yang pantas untuk duduk dikursi kepala negara dan memenuhi persyaratannya; dan

3. Ia memiliki pendapat yang kuat dan hikmah yang membuatnya (Al-Mawardi, 2000)

Tetapi selain yang memilih, didalam Islam juga disebutkan bahwa warga negara pun harus mengetahui siapa saja calonnya dan sifat - sifatnya. Menurut Jumhur ulama, mengetahui hal ini adalah wajib bagi manusia secara umum terutama warga negara yang hidup didalam negara tersebut meskipun tidak serinci yang harus diketahui oleh kalangan ahlul-halli wal- 'aqdi.

\section{METODE PENELTIAN}

Jenis penelitian yang akan digunakan adalah deskriptif kualitatif. Pendekatan kualitatif menekankan pada aspek kualitas. Artinya, mengelaborasi makna sosial dan kultural yang tidak mudah diukur dengan angka untuk menjelaskan fenomena yang ditelitinya. Data penelitian kualitatif biasanya bersifat deskriptif atau naratif. Sehingga deskriptif kualitatif artinya peneliti menggambarkan fenomena pemilihan umum di indonesia dengan sistem demokrasi one man one vote yang memiliki bebarapa kelemahan. Untuk selanjutnya peneliti menganalisa fenomena fenomena tersebut dengan pendekatan normatif lalu diteliti secara kualitatif. Jenis data yang digunakan adalah data sekunder. Penelitian ini juga dapar dinyatakan sebagai studi kepustakaan dan dokumen karena sebagian besar dari penelitian ini diambil dari data sekunder di perpustakaan, jurnal dan media informasi yang kredibilitasnya dapat dipercaya. Data sekunder yang diambil pun dapat bersifat pribadi dan publik.

\section{PEMBAHASAN}

\section{Kelemahan Pemilu di Indonesia}

Pemilu secara langsung yang sudah dilaksanakan sejak tahun 2004 sampai yang terakhir pada April 2019 yang sudah berlangsung selama tiga kali ini mempunyai beberapa kelemahan sebagai berikut ini: 
a. Sistem One Man One Vote pada pemilihan langsung yang digadang - gadangkan sebagai pelaksanaan kedaulatan rakyat dan keadilan sosial ternyata malah tidak memenuhi unsur keadilan yang ada. Seperti yang kita ketahui, keadilan dibagi menjadi dua macam dimana salah satunya adalah keadilan yang dinilai sesuai porsinya dan bukan dinilai dari sama ratanya bagian tersebut. Model pemilihan ini menjadikan suara cendekiawan disamakan dengan suara orang yang tak terpelajar. Sehingga, walaupun kelihatannya sudah sangat rasional tetapi sistem ini mengabaikan nilai kualitatis seorang calon pemimpin (Absori, 2019). Padahal sudah diajarkan didalam Islam bahwa salah satu kriteria yang harus dimiliki oleh orang yang berhak memilih adalah memiliki ilmu pengetahuan sehingga dirinya memiliki kemampuan untuk mengetahui siapa yang berhak dan pantas untuk memangku jabatan kepala negara dengan syarat - syaratnya.

b. Pihak yang menang dalam pemilihan ini ditentukan dari banyaknya suara yang didapatnya. Padahal suara terbanyak bukan berarti suara terbaik. Banyaknya suara biasanya dipengaruhi oleh komunitas yang berada dalam masyarakat tertentu, kesamaan akan tujuannya, dan lain - lain. Padahal dalam mencari seorang kepala negara dan wakilnya yang kita butuhkan adalah keselarasan rencana kerja mereka dengan tujuan negara Indonesia bukan karena kepentingan - kepentingan lainnya. Hal ini sudah dinyatakan dalam Al - Qur'an Surat An-An'am ayat 116 yang berbunyi:

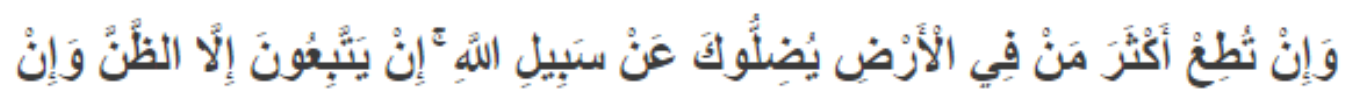

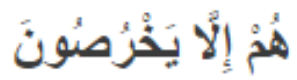

Artinya: Dan jika kamu menuruti kebanyakan orang-orang yang di muka bumi ini, niscaya mereka akan menyesatkanmu dari jalan Allah. Mereka tidak lain hanyalah mengikuti persangkaan belaka, dan mereka tidak lain hanyalah berdusta (terhadap Allah). (Al-An'am: 116)

c. Karena alasan suara terbanyak itulah pemilu di Indonesia sangat riskan sekali terjadi money politik. Cara - cara kapitalis yang transaksional ini menyebabkan ketidaksinergisan antara rakyat dengan pemimpin (Budiyanto, 2015). Pemimpin 
yang dihasilkan dengan cara seperti ini terkadang malah melepaskan tanggung jawabnya terhadap kepentingan rakyat karena merasa suara yang didapatnya sudah dibeli dengan harga pas dan tidak ada ketentuan lebih lanjut untuk mempertanggungjawabkannya. Rakyat tidak lagi bisa melakukan kontrol sosialnya sebagaimana tujuan dari kedaulatan rakyat yang diagung - agungkan.

d. Banyak menimbulkan mudharat berupa konflik sosial, membelah kerukunan masyarakat, menimbulkan suap dan korupsi. Tidak jarang pada saat panasnya gejolak pemilu, bermunculan pertikaian dan perselisihan baik didunia nyata maupun didunia maya melalui laman media sosial. Banyak orang yang masuk bui karena saling menghina dan melaporkan satu sama lain. Satu fakta mengejutkan bahwa ada seorang supir angkutan online yang tega menurunkan penumpangnya hanya karena berbeda pilihan calon presidennya (Azhari, 2019). Tentunya jika dibiarkan saja maka hal ini berpotensi merusak integritas masyarakat Indonesia yang sejak awal sudah susah payah disatukan ditengah pluralisme yang ada.

Contoh beberapa kelemahan pemilu secara langsung membuktikan bahwa walau tingkat kepuasan rakyat pada pemilu secara langsung ini sudah mencapai lebih dari 50\% tetapi jika ada cara yang lain yang lebih ideal dan sesuai dengan grundnomn negara Indonesia yaitu Pancasila. Dimana cara tersebut adalah kembali pada demokrasi kerakyatan dengan beberapa berubahan sesuai dengan nilai - nilai keislaman.

\section{Relevansi Demokrasi Kerakyatan Bernilai Keislaman dalam Mengupayakan}

\section{Terbentuknya Pemilihan Ideal di Indonesia}

Sesuai dengan yang sudah dijabarkan pada pembahasan diatas, bahwa salah satu pemilihan umum presiden ideal yang dapat dilakukan di Indonesia adalah sistem pemilihan tidak langsung yang tentunya harus dilakukan beberapa perubahan untuk upaya pembenahan. Bukan hanya kembali pada sistem pemilihan secara tidak langsung pada tahun 1999. Pada tingkatan lebih rendah, calon - calon wakil rakyat yang dibolehkan untuk ikut dalam pemilihan umum haruslah sesuai dengan bidang keahliannya masing - masing. Meskipun didalam UUD 1945 dikatakan bahwa hak politik merupakan hak setiap warga negara, tetapi jika dipandang dari kemaslahatannya tentunya akan lebih bermanfaat dan lebih mengerti jika hal - hal yang seperti ini diserahkan pada ahlinya walaupun dalam pelaksanaannya tentu saja 
wakil - wakil rakyat ini memiliki staf ahli yang akan membantu pekerjaan mereka. Pemikiran ini sejalan pemikiran Islam yaitu sesuai dengan apa yang diriwayatkan dalam Hadist Nabi riwayat Al-Bukhari yang mengajarkan, "Apabila diserahkan sesuatu urusan kepada yang bukan ahlinya, nantikanlah saat kehancuran,".

Kemudian di dalam memilih presiden dan wakil presiden inilah wakil - wakil rakyat yang sudah terpilih membawa aspirasi masyarakatnya masing - masing. Dimana dalam pemilihannya sudah disiapkan calon - calon yang dianggap mampu dalam mengemban tugas kenegaraan sebagai kepala negara sekaligus kepala pemerintahan. Calon - calon tersebut nantinya akan memaparkan rencana kerja mereka selama masa kinerja mereka saat menjabat didepan para wakil rakyat tersebut. Pada nantinya akan didiskusikan siapakah yang paling cocok untuk diangkat menjadi presiden dan wakil presiden. Tentu saja keputusan diskusi ini jika bisa dilakukan secara musyawarah mufakat bukan hasil dari voting. Hal ini tentunya sudah sangat sesuai dengan pemikiran Moh.Hatta perihal pengertian dan pelaksanaan demokrasi kerakyatan yang sudah dijabarkan pada penjelasan sebelumnya.

Tetapi, jika ingin memberlakukan pemilihan umum tidak langsung sesuai yang dijelaskan diatas. Harus ada beberapa hal yang diubah di dalam konstitusi dan sistematika peyelenggaraan negara yang ada di Indonesia. Diantara adalah sebagai berikut:

1. Negara harus mempunyai lembaga yang jelas dalam mewadahi proses pemilihan ini. Salah satu upaya yang dapat dilakukan adalah memberikan kewenangan kembali kepada Majelis Permusyawaratan Rakyat (MPR) untuk memfasilitasi proses pemilu tersebut. Dikarenakan sistem pemilu tidak langsung seperti ini sebenarnya sudah pernah dilaksanakan di Indonesia tetapi yang harus diperbaiki dalam pemilihan ini adalah sistem yang dilaksanakan didalamnya.

2. Negara harus memperjelas lagi hak politik warga negara yang dipaparkan dalam UUD 1945 karena seperti yang kita ketahui bahwa hak politik merupakan hak asasi manusia yang masuk dalam kategori derogable. Sehingga negara mempunyai wewenang untuk membatasi hak - hak tersebut terutama jika berhubungan dengan menjaga ketertiban umum (Kemenkumham, n.d.).Maksud dari memperjelas disini adalah mempertegas bahwa dalam tingkatan perwakilan rakyat yang diperbolehkan untuk mencalonkan diri adalah orang - orang yang sudah 
berkompeten baik dilihat dari riwayat pendidikan, organisasi, pengalaman berkiprah dalam bidang tersebut, dll. Tentunya dalam pemilihannya pun dibedakan menjadi beberapa komisi yang ada didalam DPR bukan hanya pemilihan DPR secara umum saja. Mungkin beberapa kalangan akan berpendapat bahwa hal ini akan mengarah pada diskriminasi beberapa golongan. Padahal jika dipikirkan lebih lanjut, hal ini lebih banyak manfaatnya ketimbang mudharatnya. Hal tersebut dikarenakan dalam beberapa pemilu terakhir yang memenangkan kursi wakil rakyat di dalam pemilu kebanyakan bukan dari kader partai politiknya melainkan anggota bermodal yang 'baru' masuk saat menjelang pemilu.

3. Negara Indonesia harus mempunyai tujuan yang jelas untuk rencana pembangunan Indonesia dalam jangka waktu panjang. Hal ini nantinya dijadikan acuan oleh para calon presiden dan wakil presiden untuk membuat rencana kinerja mereka ketika menjabat. Walaupun sekarang Indonesia sudah memiliki UU No. 5 Tahun 2004 yang berisi tentang Sistem Perencanaan Pembangunan Sosial tetapi hal tersebut tidak cukup untuk mengakomondasi rencana pembangunan Indonesia dalam waktu panjang karena secara hierarki pun posisi UU ini masih bisa digantikan dengan yang lain. Sehingga masih dianggap belum cukup kuat untuk mempertahankan idealism Indonesia yang secara umum tercantum dalam Pembukaan UUD 1945 dan harus dijabarkan lebih rinci lagi di UU yang ada dibawahnya.

Jika ketiga poin yang diatas sudah ada di Indonesia maka kemungkinan besar kita bisa beralih dari pemilihan lansung ke pemilihan tidak langsung dengan hasil akhir musyawarah mufakat dalam memilih presiden dan wakil presiden di Indonesia. Pemilihan yang seperti ini merupakan pemilihan yang tidak bertentangan dengan Pancasila dan merupakan perwujudan dari nilai - nilai luhur nenek moyang Indonesia. Selain itu, pemilihan pemimpin yang seperti inilah yang sesuai dengan nilai - nilai yang diajarkan dalam agama Islam. Manusia sebagai khalifah didalam Islam secara ketatanegaraan berarti pemimpin umat pengganti nabi untuk menjaga agama dan memakmurkan alam serta rakyatnya. Dimana menjaga Pancasila disini berarti juga merupakan salah satu usaha menjaga agama karena didalam Pancasila terkandung asas - asas yang sejalan dengan hukum Islam.

Pemilihan secara tidak langsung dengan hasil musyarawah mufakat ini juga dirancang untuk memperbanyak maslahat dan mengurangi mudharat yang ada pada 
sistem pemilihan langsung yang sedang digunakan karena dengan adanya sistem ini maka diharapkan akan menekan angka money politik yang terjadi dikancah pemerintahan Indonesia. Penurunan ini disebabkan karena yang bisa berkiprah tidak lagi hanya yang bermodal saja tetapi juga orang - orang yang berkompeten baik secara ilmu maupun pengalaman.

\section{Kesimpulan}

Pada kesimpulan ini penulis ingin memberikan beberapa catatan point penting diantaranya :

1. Pemilihan secara langsung dengan one man one vote sangat tidak tepat dan menimbulkan banyak kemudharatan dengan alasan :

a. Kondisi masyarakat Indonesia masih banyak miskin dan bodoh sehingga terbuka demokrasi kapitalistik yang ditandai politik transaksional berupa politik uang. Masyarakat miskin dan bodoh tidak lagi memikirkan siapa sosok ideal untuk jadi pemimpin, tetapi mereka lebih memilih siapa yang beri mereka uang untuk makan.

b. Kondisi point a, diperparah tingkat pendidikan indonesia masyarakat Indonesia masih rendah sehingga orang tidak bisa berpikir rasional

c. Akibat fenomena di atas maka seorang figur pemimpin yang cerdas dan amanat pasti kalah dengan lawan yang memiliki modal yang besar karena demokrasi dengan pemilihan langsung adalah one man one vote. Artinya suara seorang pemilih yang cerdas dan memahami kreteria pemimpin yang baik sama nilainya dengan seorang yang miskin dan bodoh yang riskan untuk disuap.

2. Atas dasar alasan-alasan di atas sudah saatnya pemerintah menggunakan sistem pemilihan dengan keterwakilan. Hal ini sejalan dengan sila ke empat pancasila, selain itu juga dapat menghemat biaya pemilu yang cukup besar dan menutup resiko konflik horizontal.

3. Alasan perubahan sistem pemilihan langsung dengan one man one vote, karena selama ini banyak terjadi hal hal yang jauh dari nilai-nilai keislaman dan nilai -nilai agama dan moralitas. Sehingga sudah saatnya pemilu dilakukan dengan sistem keterwakilan yang saat ini mudharatnya lebih sedikit dari pemilihan langsung. 


\section{REFERENSI}

Absori. (2019, Desember 10). Penataan Wewenang dan Tugas Majelis Permusyawaratan Rakyat (MPR). Seminar Nasional Majelis Permusyawaratan Rakyat Republik Indonesia (MPR RI) dan Universitas Muhammadiyah Surakarta (UMS). Surakarta.

Al-Mawardi, I. (2000). Hukum Tata Negara dan Kepemimpinan dalam Takaran Islam. Terjemahan: Abdul Hayyie Al-Kattani, Kamaluddin Nurdin. Jakarta: Gema Insani Press.

Azhari, J. R. (2019, Februari 26). Turunkan Penumpang karena Beda Pilihan Capres, Driver Grab. Retrieved from Kompas: https://megapolitan.kompas.com/read/2019/02/26/14450751/turunkan-penumpangkarena-beda-pilihan-capres-driver-grab-dinonaktifkan

Basyir, A. A. (2000). Negara dan Pemerintahan Islam. Yogyakarta: UIN Press.

Budiyanto, S. (2012, September 17). Pemilihan Langsung Bertentangan dengan Pancasila. Retrieved from Kompasiana: https://www.kompasiana.com/gavin/55179d5ea333113107b65f9d/pemilihanlangsung-bertentangan-dengan-pancasila

CNN Indonesia. (2019, Desember 10). Survei SMRC: Mayoritas Warga Anggap Pilpres 2019 Jurdil. Retrieved from Indonesia: https://www.cnnindonesia.com/nasional/20190616162335-32-403705/survei-smrcmayoritas-warga-anggap-pilpres-2019-jurdil

Fahmi, K. (2011). Pemilihan Umum dan Kedaulatan Rakyat. Jakarta: Raja Grafindo Persada.

Kemenkumham. (n.d.). Hak Politik Warga Negara (Sebuah Perbandingan Konstitusi). Retrieved from Kemenkumham: http://ditjenpp.kemenkumham.go.id/htn-danpuu/2941-hak-politik-warga-negara-sebuah-perbandingan-konstitusi.html

Matompo, O. S. (2012). Pembatasan Terhadap Hak Asasi Manusia dalam Prespektif Keadaan Darurat. Jurnal Media Hukum Vol. 21, No. 1, 57-72.

Movanita, A. N. (2019, Oktober 18). Survei Litbang Kompas: 58,8\% Responden Puas Kinerja Pemerintahan Jokowi-JK. Retrieved from Kompas: https://nasional.kompas.com/read/2019/10/18/15412231/survei-litbang-kompas-588persen-responden-puas-kinerja-pemerintahan-jokowi?page $=$ all

Prihatmoko, J. J. (2004). Pemilu 2004 dan Konsolidasi Demokrasi. Semarang: LP21 Press.

Shobron, S. (2004). Islam dan Demokrasi: Implementasinya dalam Gerakan Islam Indonesia. Akademika, Jurnal Kebudayaan Vol. 4, No. 1, 52-68.

Sutrisno, T. (2013). Pemikiran Hatta Tentang Sistem Demokrasi Kerakyatan. Yogyakarta, Indonesia: Universitas Negeri Yogyakarta. 